\title{
C-reactive protein and serological indices of disease activity in systemic lupus erythematosus
}

\author{
J. V. BERTOUCH, ${ }^{1}$ P. J. ROBERTS-THOMPSON ${ }^{1}$ P. H. FENG, ${ }^{2}$ \\ AND J. B R A D LE Y ${ }^{1}$ \\ From the ${ }^{1}$ Department of Clinical Immunology, Flinders Medical Centre, South Australia, and ${ }^{2}$ Singapore \\ General Hospital, Singapore
}

SUMMARY The concentration of C-reactive protein (CRP) in sera from 70 patients with systemic lupus erythematosus (SLE) showed no correlation with commonly accepted laboratory indices of disease activity. Most patients had detectable serum CRP, but in some patients CRP was not found despite repeated testing. This absence of a CRP response did not appear to be related to medication. In some patients high levels of CRP were seen in the absence of infection. Measurement of serum CRP in SLE is unlikely to be useful in the laboratory diagnosis of disease activity.

C-reactive protein (CRP) is a major acute-phase reactant whose concentration may rise with tissue inflammation or necrosis, infectious diseases, and malignancy. CRP levels have been used to monitor disease activity and response to therapy in a number of rheumatic diseases, including rheumatoid arthritis, ${ }^{1}$ vasculitic syndromes, ${ }^{2}$ and ankylosing spondylitis. ${ }^{3}$ In systemic lupus erythematosus (SLE) the role of CRP is less clear, and there have been a number of conflicting reports as to the incidence and significance of elevated CRP levels. Early studies ${ }^{4-6}$ indicated that patients with SLE rarely have positive CRP sera but that a positive result suggests superimposed infection. These studies used a semiquantitative capillary precipitation technique to detect CRP, and false positive results can occur in the presence of IgM antibodies such as rheumatoid factor. ${ }^{\text {? }}$

Subsequent studies $^{8}{ }^{9}$ using radial immunodiffusion $^{10}$ suggested that CRP elevation in the course of SLE is most frequently associated with exacerbations of clinical disease activity and does not necessarily indicate the presence of infection. Becker et al., ${ }^{11}$ using an electroimmunoassay technique to measure CRP, found that higher concentrations were seen in clinically active disease but that le vels greater than 60 $\mathrm{mg} / \mathrm{l}$ suggested intercurrent infection. All of these papers have correlated CRP levels with clinical manifestation of disease activity. A number of immunological investigations including doublestandard DNA antibodies (DNA Abs), circulating

Accepted for publication 10 January 1983.

Correspondence to Professor J. Bradley, Department of Clinical Immunology, Flinders Medical Centre, Bedford Park, South Australia 5042. immune complexes (CICs), and $\mathrm{C} 3$ and $\mathrm{C} 4$ are considered to be useful in laboratory monitoring of disease activity in SLE.

The purpose of this study was to determine whether CRP levels could be correlated with any of these serological indices.

\section{Patients and methods}

Seventy patients fulfilling the American Rheumatology Association criteria for the classification of SLE were included in the study. The group consisted of subjects of Chinese and Indian descent resident in Singapore who attended the LE Clinic at Singapore General Hospital. None of the patients had clinical evidence of any infective process at the time of sampling. All patients were seen by one of us (J.B.), and clinical details and serum samples were collected and transported at $-20^{\circ} \mathrm{C}$ to Adelaide, where they were stored at this temperature until required.

CRP was measured by means of radial immunodiffusion. ${ }^{10}$ The diameters of precipitin rings were measured with a magnifying $(\times 7)$ calibrated eyepiece, and the smallest diameter ring that could be measured confidently corresponded to a concentration of $6 \mu \mathrm{g} / \mathrm{ml}(6 \mathrm{mg} / \mathrm{l})$. The CRP standard was obtained from Behringwerke AG, West Germany, and the anti-CRP antiserum was supplied by Dako Immunoglobulins, Denmark. DNA Abs were measured by the Pincus modification of the Farr technique. ${ }^{12} \mathrm{C} 3, \mathrm{C} 4$ and alpha-1-antitrypsin $(\alpha 1 \mathrm{AT})$ were measured by a nephelometric technique with a Technicon Autoanalyser. CICs were measured by the fluid phase Clq binding assay. ${ }^{13}$ 
Laboratory results regarded as abnormal were: $\mathrm{CRP}>6 \mu \mathrm{g} / \mathrm{ml}(6 \mathrm{mg} / \mathrm{l})$ (normal $<6$ as obtained from 100 blood donors), DNA Abs $>30 \%$, C $3<55$ $\mathrm{mg} / 100 \mathrm{ml}(0.55 \mathrm{~g} / \mathrm{l})$ (normal range $55-120 \mathrm{mg} / 100$ $\mathrm{ml})(0.55-1.20 \mathrm{~g} / \mathrm{l})), \mathrm{C} 4<20 \mathrm{mg} / 100 \mathrm{ml}(0.2 \mathrm{~g} / \mathrm{l})$ (normal range $20-50 \mathrm{mg} / 100 \mathrm{ml})(0 \cdot 2-0 \cdot 5 \mathrm{~g} / \mathrm{l})), \alpha 1$ AT $<0 \cdot 85 \mathrm{mg} / \mathrm{ml}(0 \cdot 85 \mathrm{~g} / \mathrm{l})$ (normal range $0 \cdot 85-2 \cdot 13$ $\mathrm{mg} / \mathrm{ml}($ or $\mathrm{g} / \mathrm{l})$ ), and CICs $>3$ units.

The results were set out in $2 \times 2$ contingency tables and analysed by the chi-squared test. Analysis of DNA Abs, C3, and C4 results was performed by the Kendall coefficient of concordance. ${ }^{14}$

\section{Results}

CRP was detectable in 55 patients. Thirteen of them had levels greater than $6 \mu \mathrm{g} / \mathrm{ml}$ with a range from $6.8 \mu \mathrm{g} / \mathrm{ml}$ to $99.5 \mathrm{~g} / \mathrm{ml}$. The remaining 42 patients in this group had concentrations less than $6 \mu \mathrm{g} / \mathrm{ml}$ but a visible precipitation ring. (SI conversion $=\mu \mathrm{g} / \mathrm{ml}=\mathrm{mg} / \mathrm{l})$. DNA Abs were elevated in 42 patients. C3 was reduced in 39 patients and C4 reduced in 27 patients. $\alpha 1 \mathrm{AT}$ was in the normal range in 50 patients and elevated in 20 patients. CICs were elevated in 20 patients. The complete results for patients with an elevated CRP are shown in Table 1. Results for those patients with no detectable CRP are shown in Table 2 . In the overall group of 70 patients there was no significant correlation between CRP levels and DNA Abs, CICs, C3, C4, or $\alpha 1$ AT ( $>0.05$, chi-squared test). By contrast there was a highly significant correlation between elevated DNA Abs and reduced levels of $\mathrm{C} 3$ and $\mathrm{C} 4(\mathrm{~W}=0 \cdot 7$, Kendall coefficient of concordance). The correlation between elevated CICs, elevated DNA Abs, reduced $\mathrm{C} 3$, and reduced $\mathrm{C} 4$ was not significant.

Table 1 Summary of serological indices in those patients with an elevated CRP

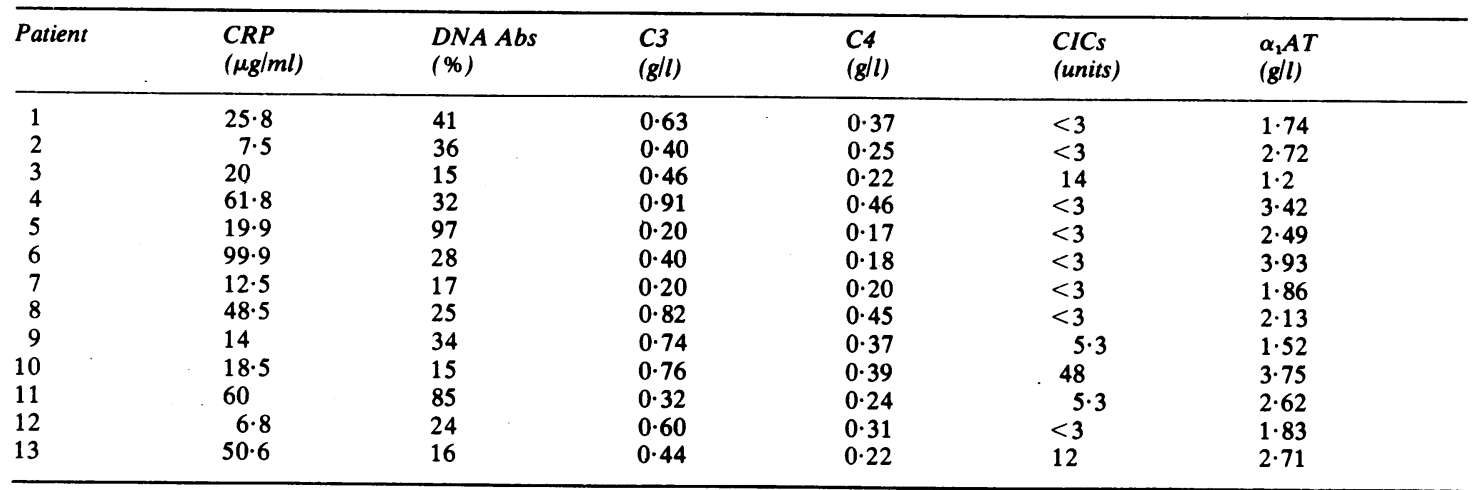

Si conversion: CRP $\mu \mathrm{g} / \mathrm{ml} \times 1=\mathrm{mg} / 1$.

Table 2 Summary of serological indices in those patients with no detectable CRP

\begin{tabular}{|c|c|c|c|c|c|c|}
\hline Patient & $\begin{array}{l}C R P \\
(\mu g / m l)\end{array}$ & $\begin{array}{l}\text { DNA Abs } \\
(\%)\end{array}$ & $\begin{array}{l}C 3 \\
(g / l)\end{array}$ & $\begin{array}{l}C 4 \\
(g / l)\end{array}$ & $\begin{array}{l}\text { CICs } \\
\text { (units) }\end{array}$ & $\begin{array}{l}\alpha_{1} A T \\
(m g / m l)\end{array}$ \\
\hline 14 & - & 94 & 0.11 & 0.5 & $<3$ & 1.44 \\
\hline 15 & - & 12 & $0 \cdot 37$ & $0 \cdot 21$ & $<3$ & $1 \cdot 38$ \\
\hline 16 & - & 48 & 0.89 & 0.33 & $<3$ & $1 \cdot 71$ \\
\hline 17 & - & 31 & $0 \cdot 63$ & $0 \cdot 18$ & $<3$ & $2 \cdot 3$ \\
\hline 18 & - & 14 & 0.53 & $0 \cdot 29$ & $<3$ & 1.68 \\
\hline 19 & - & 84 & $0 \cdot 22$ & $0 \cdot 14$ & $<3$ & 1.44 \\
\hline 20 & - & 47 & 0.47 & $0 \cdot 15$ & $<3$ & 1.92 \\
\hline 21 & - & 16 & 0.79 & $0 \cdot 22$ & $<3$ & 1.92 \\
\hline 22 & - & 44 & $0 \cdot 23$ & 0.09 & $9 \cdot 4$ & $1 \cdot 74$ \\
\hline 23 & - & 47 & 0.48 & 0.17 & $<3$ & 1.86 \\
\hline 24 & - & 96 & 0.29 & $0 \cdot 17$ & 23 & $2 \cdot 1$ \\
\hline 25 & - & 12 & 0.55 & $0 \cdot 28$ & $<3$ & 1.08 \\
\hline 26 & - & 78 & 0.26 & $0 \cdot 21$ & $3 \cdot 5$ & $2 \cdot 04$ \\
\hline 27 & - & 66 & 0.34 & 0.9 & $<3$ & 1.68 \\
\hline 82 & - & 48 & $0 \cdot 34$ & 0.2 & 63 & $1 \cdot 8$ \\
\hline
\end{tabular}

SI conversion: CRP $\mu \mathrm{g} / \mathrm{ml} \times 1=\mathrm{mg} / \mathrm{l}$. 


\section{Discussion}

We have shown that CRP levels do not correlate with commonly accepted laboratory indices of disease activity in SLE. This is in contrast with rheumatoid arthritis, where CRP levels correlate significantly with clinical ${ }^{15}$ radiological $^{16}$ and serological ${ }^{17}$ indices of disease activity. The present study used the Mancini radial immunodiffusion technique for CRP measurement. The results show that 42 patients had visible precipitation rings which could not be measured accurately because of their small diameter. More sensitive measurement techniques not available to us such as radioimmunoassay would have allowed quantitation of these results. Nevertheless CRP was elevated in only 13 patients, and none had clinical evidence of infection. Of these, 6 patients were studied on presentation and in the absence of any treatment and 7 were receiving corticosteroids. Fifteen patients had no visible precipitation ring. Further serum samples from 5 of these patients were measured subsequently, and still no precipitation ring was visible. Four of these patients were sampled on presentation and without treatment, and the remaining 11 were receiving corticosteroids. Seven of these 11 patients had active disease both clinically and serologically. It is known that corticosteroids do not directly influence the CRP response unless underlying disease activity is modified, ${ }^{18}$ and it has been previously shown in SLE that there is no correlation between CRP levels and prednisolone dose rate. ${ }^{19}$ Our findings are in accord with these reports, as those patients with absent CRP had both active disease and were receiving corticosteroids at the time of serum collection.

The absence of CRP in some patients has been previously noted by Morrow et al., ${ }^{9}$ and it has previously been suggested by Becker et al. ${ }^{11}$ that hereditary effects on production of CRP in response to certain stimuli may account for this unresponsiveness. It was further suggested by Becker et al. ${ }^{11}$ that, as CRP interacts with complement, then impairment of the acute-phase response on a genetic basis may be important in the pathogenesis of inflammatory disease. It should be emphasised that single serum samples only were obtained from each patient, and previous reports ${ }^{59}$ have shown that serial CRP levels from the same patient may show quite marked fluctuations.

Although we did not attempt to examine fully the acute-phase proteins in this study, it is of interest that all patients had either normal or elevated $\alpha_{1}$ AT levels. A report on serum amyloid-A protein (SAA), another acute-phase protein, in a number of inflammatory diseases, including SLE, has recently been published. ${ }^{20} \mathrm{SAA}$ levels were found to be lower in
SLE than rhe umatoid arthritis and juvenile chronic arthritis and tended to parallel CRP concentrations in these diseases. There are many other acute-phase proteins, and a more comprehensive study of their behaviour in SLE would be particularly interesting.

There was a significant correlation between elevated DNA Abs, low C3, and low $\mathrm{C} 4$, confirming the impression that these indices tend to parallel each other. The lack of correlation with CICs is undoubtedly due to the fluid phase assay used. It is well recognised that the solid phase Clq binding assay is more specific for the CICs found in SLE. ${ }^{21}$

In conclusion, CRP levels do not correlate with some of the commonly accepted indices of disease activity in SLE and are not likely to be helpful in the laboratory assessment of disease activity.

\section{References}

1 Hedlund P. Clinical experimental studies on C-reactive protein (acute phase protein). Acta Med Scand 1961; 361 (suppl): 35-71.

2 Parish W E. Studies on vasculitis. VII. C-reactive proteins as a substance perpetuating chronic vasculitis. Occurence in lesions and concentrations in sera. Clin Allergy 1976; 6: 543-50.

3 Cowling $P$, Ebringer $R$, Cawdell $D$, Ishii $M$, Ebringer $A$. C-reactive protein, ESR, and klebsiella in ankylosing spondylitis. Ann Rheum Dis 1980; 39: 45-9.

4 Hill A G S. C-reactive protein in the chronic rhe umatic diseases. Lancet 1951; ii: 807-12.

5 Honig S, Gorevic P, Weissman G. C-reactive protein in systemic lupus erythematosus. Arthritis Rheum 1977; 20: 1065-9.

6 Bravo M G, Alarcon-Segovia D. C-reactive protein in the differential diagnosis between infection and disease reactivation in SLE. J Rheumatol 1981; 8: 291-4.

7 Deyo $R$ A, Pope $R \mathbf{M}$, Persellin $R \mathbf{H}$. Interference by rhe umatoid factor with the detection of $\mathrm{C}$-reactive protein by the latex agglutination method.J Rheumatol 1980; 7: 279-87.

8 Zein N, Ganuza C, Kushner I. Significance of serum C-reactive protein elevation in patients with systemic lupus erythematosus. Arthritis Rheum 1979; 22: 7-12.

9 Morrow W J W, Isenberg D A, Parry H F, Snaith M L. C-reactive protein in sera from patients with systemic lupus erythematosus. J Rheumatol 1981; 8: 599-604.

10 Mancini G, Carbonara A O, Hermans J F. Immunochemical quantification of antigens by single radial immunodiffusion. Immunochemistry 1965; 2: 235-54.

11 Becker G J, Waldburger M, Hughes G R V, Pepys M B. Value of $\mathrm{C}$-reactive protein measurement in the investigation of fever in systemic lupus erythematosus. Ann Rheum Dis 1980; 39: 50-2.

12 Pincus T. Immunochemical conditions affecting the measurement of DNA antibodies using ammonium sulphate precipitation. Arthritis Rheum 1971; 14: 623-30.

13 Nydegger UE, Lambert P H, Gerber H, Miescher P A. Circulating immune complexes in the serum in systemic lupus erythematosus and in carriers of hepatitis B antigen: quantitation by binding to radiolabelled Clq. J Clin Invest. 1974; 54: 297-309.

14 Siegel S. Non-parametric statistics for the behavioural sciences. New York: McGraw-Hill, 1956.

15 McConkey B, Crockson R A, Crockson A P. The assessment of rheumatoid arthritis. $Q J$ Med 1972; 41: 115-25.

16 Amos R S, Constable T J, Crockson R A, Crockson A P, 
McConkey B. Rheumatoid arthritis: relation of serum C-reactive protein and erythrocyte sedimentation rates to radiographic changes. $\mathrm{Br}$ Med J 1977; í: 195-7.

17 Pepys M B. C-reactive protein fifty years on. Lancet 1981; i: 653-7.

18 Lambert P H, Dixon F J, Zubler R H, et al. A WHO collaborative study for the evaluation of eighteen methods for detecting immune complexes in serum. J Clin Lab Immunol 1978; 32: 1253-88.

19 Pereira da Silva J A, Elkon K B, Hughes G R V, Dyck R F, Pepys $M$ B. C-reactive protein levels in systemic lupus erythematosus: a classification criterion? Arthritis Rheum 1980; 23: 770-1.

20 de Beer F C, Fagan E A, Hughes G R V, Mallya R K, Lanham J G, Pepys $M$ B. Serum amyloid-A protein concentration in inflammatory diseases and its relationship to the incidence of reactive systemic amyloidosis. Lancet 1982; it: 231-234.

21 Mallya R K, Vergani D, Tee D E H, et al. Correlation in rheumatoid arthritis of concentrations of plasma C3d, serum rheumatoid factor, immune complexes and $\mathrm{C}$-reactive protein with each other and with clinical features of disease activity. Clin Exp Immunol 1982; 48: 747-53. 